\title{
APLIKASI KLASIFIKASI STATUS GIZI BALITA MENGGUNAKAN METODE NAÏVE BAYES BERBASIS ANDROID
}

\author{
Eva Darnila ${ }^{\bowtie}$, Maryana, Muhammad Azmi \\ Program Studi Teknik Informatika, Universitas Malikussaleh, Aceh Utara, Indonesia \\ Email: eva.darnila@unimal.ac.id
}

DOI: https://doi.org/10.46880/jmika.Vol5No2.pp135-141

\begin{abstract}
Malnutrition is a condition that a person experience because the lack of nutrient intake or the amount of nutrients that exist is still below standard. nutritional problems are most commonly experienced by toddlers. Nutritional status in toddlers is a benchmark of the health condition of toddlers. The nutritional status of toddlers can currently be measured based on anthropometric index using WHO standards. Anthropometrics is an assessment of the nutritional status of toddlers determined through measurements of the human body In this study measurement of nutritional status using a technique in data mining namely Naïve Bayes Method that aims to facilitate health centers in measuring the nutritional status of toddlers quickly through android-based applications. Naïve Bayes method performs nutritional status classification of toddlers that will produce a classification very thin, thin, normal and fat. Based on data taken from banda sakti health center Lhokseumawe city which then carried out the classification process, obtained the results of nutritional status "skinny" with data testing male sex, weight $7.4 \mathrm{~kg}$ and height 64.6.
\end{abstract}

Keyword: Data Mining, Nutrition Status of Toddlers, Classification, Nä̈ve Bayes Methods.

\section{ABSTRAK}

Gizi buruk merupakan suatu keadaan yang dialami seseorang dikarenakan kurangnya asupan nutrisi atau jumlah nutrisi yang ada masih dibawah standar. masalah gizi paling sering dialami oleh balita. Status gizi pada balita merupakan tolak ukur kondisi kesehatan balita. Status Gizi balita saat ini bisa diukur berdasarkan indeks antropometri yang merupakan standar baku WHO. Antropometri adalah penilaian status gizi balita yang ditentukan melalui pengukuran tubuh manusia. Pada penelitian ini pengukuran status gizi menggunakan suatu teknik dalam data mining yaitu Metode Naïve Bayes yang bertujuan untuk mempermudah puskesmas dalam melakukan pengukuran status gizi balita secara cepat melalui aplikasi berbasis android. Metode Naïve Bayes melakukan klasifikasi status gizi balita yang akan menghasilkan klasifikasi sangat kurus, kurus, normal dan gemuk. Berdasarkan data balita yang diambil dari puskesmas Banda Sakti Kota Lhokseumawe yang kemudian dilakukan proses klasifikasi, diperoleh hasil status gizi "kurus" dengan data pengujian jenis kelamin laki-laki, berat badan 7,4 kg dan tinggi badan 64,6.

Kata Kunci: Data Mining, Status Gizi Balita, Klasifikasi, Metode Nä̈ve Bayes.

\section{PENDAHULUAN}

Gizi buruk adalah kondisi yang dialami seseorang dikarenakan kekurangan asupan nutrisi atau jumlah nutrisi yang dikonsumsi berada dibawah standar. Nutrisi yang dibutuhkan diantaranya karbohidrat, protein serta kalori. Salah satu permasalhan gizi yang paling utama dan paling sering dialami bayi usia di bawah lima tahun (balita) adalah kekurangan energi protein (Rahmawati, 2017).

Berdasarkan data Profil Kesehatan Aceh 2018, kasus gizi buruk Kabupaten Aceh Utara menempati urutan pertama dengan jumlah sebanyak 429 kasus, diikuti kabupaten Bireuen sebanyak 17 kasus. Dari data tersebut yang mendapatkan perawatan di Aceh Utara hanya $5 \%$ dari jumlah kasus sedangkan kabupaten Bireuen dan kabupaten lainnya di Aceh mendapat perawatan $100 \%$ dari kasus yang ditemukan (Dinas Kesehatan Aceh, 2018).

Angka balita gizi buruk yang sangat tinggi, maka diperlukan pendeteksian awal bagi balita untuk mengurangi kasus gizi buruk, salah satu langkah yang dapat dilakukan ialah dengan menguji status gizi balita, yang bertujuan untuk mendapatkan informasi status balita gizi secara cepat agar mempermudah instansi kesehatan melakukan penanganan pada balita.

Untuk melakukan pengujian status gizi balita, dapat dilakukan dengan menggunakan sebuah teknik dalam data mining yaitu klasifikasi. Klasifikasi 
melakukan analisis data pelatihan untuk dapat membentuk aturan klasifikasi yang biasa disebut sebagai proses belajar atau pelatihan. Selanjutnya, klasifikasi akan menganalisis data pengujian untuk menguji aturan klasifikasi yang telah diperoleh dari proses pelatihan (Putri, Sendari, \& Widiyaningtyas, 2018).

Salah satu algoritma klasifikasi yang sering dipakai ialah algoritma naïve bayes. Algoritma Naïve Bayes adalah algoritma yang memanfaatkan teori kemungkinan, yakni memprediksi kemungkinan di masa depan berdasarkan pengalaman pada masa sebelumnya (Hariri \& Pamungkas, 2016).

\section{METODE}

\section{Metode Naïve Bayes}

Naïve Bayes adalah sebuah metode pengelompokan statistik yang bisa dipakai untuk memprediksi probabilitas anggota suatu class. Naïve Bayes juga mempunyai akurasi dan kecepatan yang sangat kuat ketika diaplikasikan pada database dengan big data (Widiastuti, Santosa, \& Supriyanto, 2014). Teorema Bayes memiliki bentuk umum sebagai berikut:

$$
P(H \mid X)=\frac{P(X \mid H) P(H)}{P(X)}
$$

Keterangan:

$X \quad$ : Data dengan class yang belum diketahui

$H \quad$ : Hipotesis data $\mathrm{X}$ merupakan suatu class spesifik

$P(H \mid X)$ : Probabilitas hipotesis $\mathrm{H}$ berdasarkan kondisi $\mathrm{X}$

$P(H) \quad$ : Probabilitas hipotesis $\mathrm{H}$ (prior probability)

$P(X \mid H)$ : Probabilitas $\mathrm{X}$ berdasarkan kondisi pada hipotesis $\mathrm{H}$

$P(X) \quad$ : Probabilitas dari $\mathrm{X}$

Jika atribut ke-i bersifat diskret, maka $P(H \mid X)$ diestimasi sebagai frekuensi relatif dari sampel yang memiliki nilai $H$ sebagai atribut ke i dalam kelas $X$. Namun, jika atribut ke-i bersifat kontinu, maka $P(H \mid X)$ diestimasi dengan fungsi densitas Gauss (Putri et al., 2018).

$$
P\left(X_{i}=x_{i} \mid Y=y_{j}\right)=\frac{1}{\sqrt{2 \pi \sigma_{i j}}} e^{-\frac{\left(x_{i}-\mu\right)^{2}}{2 \sigma_{i j}^{2}}}
$$

Keterangan:

$P$ : Peluang

$X_{i}:$ Atribut ke i

$x_{i}$ : Nilai atribut ke $\mathrm{i}$

$Y$ : Kelas yang dicari $y_{j}:$ Sub kelas Y yang dicari

$\mu$ : Mean, menyatakan rata-rata seluruh atribut

$\sigma$ : Standar deviasi

Persamaan untuk menghitung nilai simpangan baku (standar deviasi) dapat dilihat dibawah ini (Guntur, Santony, \& Yuhandri, 2018):

$$
\sigma=\sqrt{\frac{\sum_{i=1}\left(x_{i}-\mu\right)^{2}}{n}}
$$

Keterangan:

$\sigma$ : Standar deviasi

$x_{i}$ : Data ke i

$\mu \quad$ : Rata-rata populasi

$n$ : Jumlah data

Dan rumus yang digunakan untuk menghitung nilai rata-rata (mean) dapat dilihat sebagai berikut (Guntur et al., 2018):

$$
\mu=\frac{\sum_{i=1}^{n} x_{i}}{n}
$$

Keterangan:

$\mu$ : Nilai rata-rata(mean)

$x_{i}$ : Data ke i

$n$ : Jumlah data

\section{Skema Sistem}

Skema sistem untuk pengolahan data dengan menggunakan metode naïve bayes sebagai berikut:

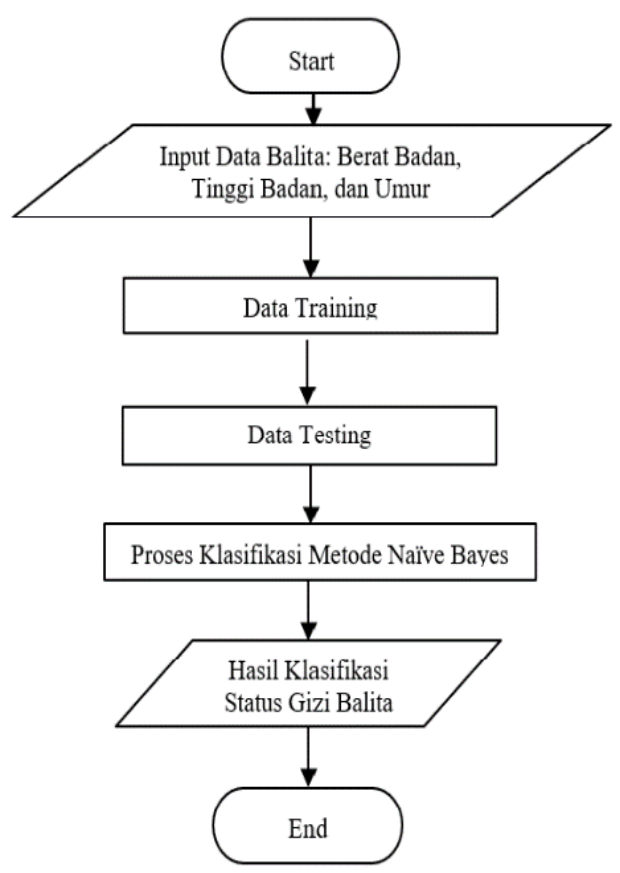

Gambar 1. Skema Sistem 


\section{HASIL DAN PEMBAHASAN \\ Data Training}

Data training merupakan bahan baku informasi yang didapatkan berdasarkan data yang ada di lapangan. Pada penelitian ini data didapatkan dari Puskesmas Banda Sakti Kota Lhokseumawe. Data training pada penelitian ini berjumlah 4072 data balita, dimana data training balita yang terdiri dari 28 balita berstatus gizi sangat kurus, 278 kurus, 3677 normal dan 89 gemuk. data training dapat dilihat pada tabel (1) berikut:

Tabel 1. Data Training Status Gizi Balita

\begin{tabular}{|c|c|c|c|c|}
\hline No & Jenis Kelamin & Berat Badan & Tinggi Badan & Status Gizi \\
\hline 1 & $\mathrm{P}$ & 11 & 94 & Kurus \\
\hline 2 & $\mathrm{P}$ & 14,4 & 97,6 & Normal \\
\hline 3 & $\mathrm{~L}$ & 17,1 & 99 & Normal \\
\hline$\ldots$ & $\ldots$ & $\ldots$ & $\ldots$ & $\ldots$ \\
\hline$\ldots$ & $\ldots$ & $\ldots$ & $\ldots$ & $\ldots$ \\
\hline 4070 & $\mathrm{P}$ & 7,8 & 72 & Normal \\
\hline 4071 & $\mathrm{P}$ & 3 & 51 & Kurus \\
\hline 4072 & $\mathrm{P}$ & 2,8 & 51 & Sangat Kurus \\
\hline
\end{tabular}

\section{Data Testing}

Data testing (data uji) merupakan bahan baku yang sengaja dibuat untuk membantu proses penelitian dalam sistem data mining, secara lebih rinci data testing dapat di lihat pada tabel 2 berikut:

Tabel 2. Data Testing Balita

\begin{tabular}{|c|c|c|c|c|}
\hline No & Jenis Kelamin & Berat Badan & Tinggi Badan & Status Gizi \\
\hline 1 & L & 7,4 & 64,6 & $?$ \\
\hline
\end{tabular}

\section{Penentuan Hasil Klasifikasi}

Apabila data testing telah dimasukkan, klasifikasi status gizi balita dapat ditentukan melalui langkah berikut:

\section{Menghitung Mean dan Standar Deviasi}

Perhitungan mean dan standar deviasi dilakukan pada setiap atribut yang bersifat kontinu atau numerik seperti berat badan dan tinggi badan. Mean dan standar deviasi untuk masing-masing kelas atau label Sangat Kurus, Kurus, Normal dan Gemuk.

Untuk atribut berat badan, hasil perhitungan mean dan standar deviasi diperoleh sebagai berikut:

$$
\begin{aligned}
& \mu_{\text {sangat } \text { kurus }=\frac{3+5,8+2,8+2,7+3,2+\cdots+3,2+3,2+7+2,8+2,8}{28}}=4,857142857 \\
& \mu_{\text {kurus }}=\frac{11+10+10,9+5+8+\cdots+12+12+11+12+3}{278}=8,492446043 \\
& \mu_{\text {normal }}=\frac{14,5+17,1+18+16,6+15,8+\cdots+15+16,7+12+3,2+7,8}{3677}=12,28550721 \\
& \mu_{\text {gemuk }=}=\frac{19+9+4,5+5,8+6+\cdots+12+20+17+20+17}{89}=16,83258427
\end{aligned}
$$

$\sigma$
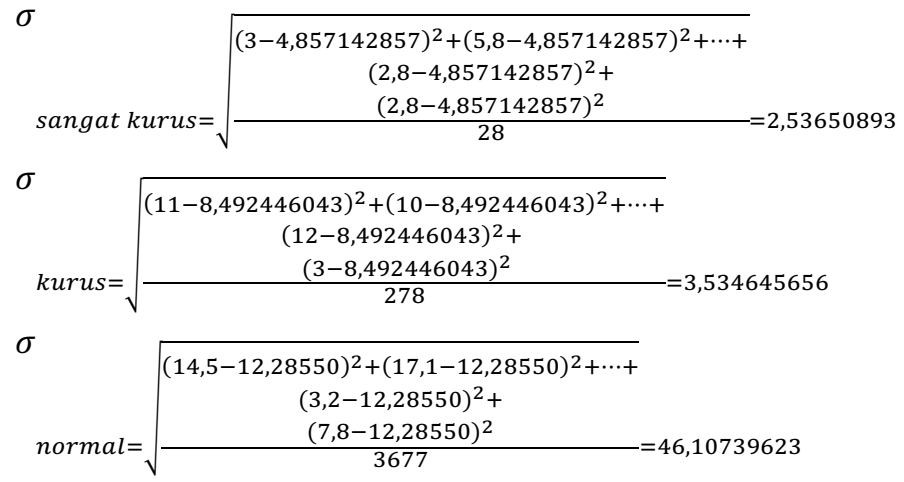


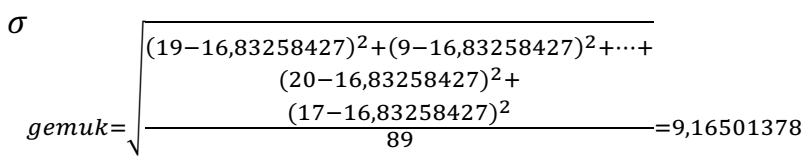

Selanjutnya kita hitung mean dan standar deviasi pada atribut tinggi badan, hasil perhitungan diperoleh sebagai berikut:
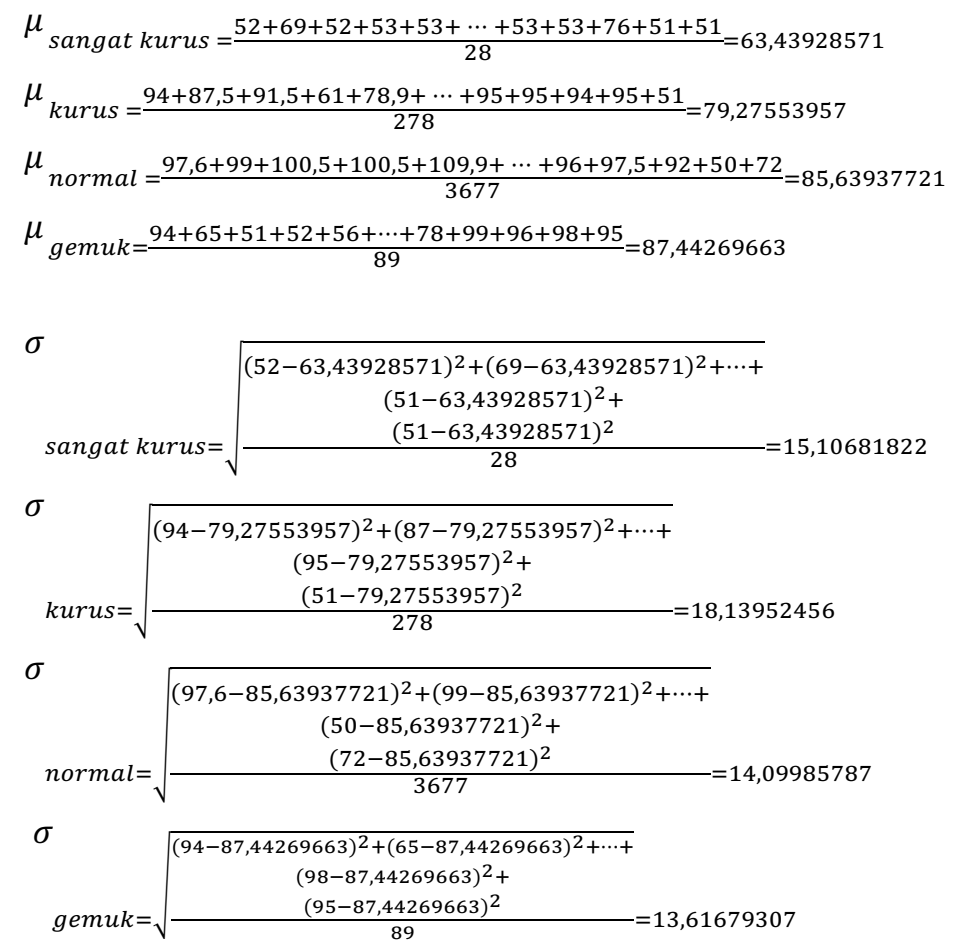

\section{Menghitung Probabilitas}

Menghitung $\mathrm{P}(\mathrm{Hi})$

Perhitungan $\mathrm{P}(\mathrm{Hi})$ adalah perhitungan jumlah class / label. Jumlah class / label ada 4 yaitu sangat kurus, kurus, normal dan gemuk. Perhitungan dilakukan pada setiap label sehingga diperoleh hasil perhitungan dari keempat label sebagai berikut:

$\mathrm{P}(\mathrm{Y}=$ label $/$ class $)=$ Jumlah label class $/$ Total jumlah data

$\mathrm{P}($ Sangat Kurus $)=\frac{28}{4072}=0,006876228$

$\mathrm{P}($ Kurus $)=\frac{278}{4072}=0,06827112$

$\mathrm{P}($ Normal $)=\frac{3677}{4072}=0,902996071$

$$
\begin{aligned}
& P(\text { Gemuk })=\frac{89}{4072} \\
& =0,021856582
\end{aligned}
$$

Menghitung $\mathrm{P}(\mathrm{X} \mid \mathrm{Hi})$

Perhitungan $\mathrm{P}(\mathrm{X} \mid \mathrm{Hi})$ adalah perhitungan jumlah kasus yang sama dengan class yang sama. Pada penelitian ini perhitungan $\mathrm{P}(\mathrm{X} \mid \mathrm{Hi})$ dilakukan pada atribut jenis kelamin, karena jenis kelamin merupakan atribut diskrit. Perhitungan juga dilakukan berdasarkan empat label, sehingga diperoleh hasil sebagai berikut:

Label class $\mathrm{H}=$ Sangat Kurus

Jumlah data dengan label class Sangat Kurus yaitu 28, hasil perhitungannya sebagai berikut: 
$\mathrm{P}\left(\right.$ Jenis Kelamin $=$ Laki - laki $\mid$ Sangat Kurus $=\frac{14}{28}=0,5$

$\mathrm{P}\left(\right.$ Jenis Kelamin $=$ Perempuan $\mid$ Sangat Kurus $=\frac{14}{28}=0,5$

Label class $\mathrm{H}=$ Kurus

Jumlah data dengan label class $\mathrm{Y}=$ Kurus yaitu 278, hasil perhitungannya sebagai berikut:

$\mathrm{P}\left(J e n i s\right.$ Kelamin $=$ Laki - laki $\mid$ Kurus $=\frac{161}{278}=0,579136691$

$\mathrm{P}\left(\right.$ Jenis Kelamin $=$ Perempuan $\mid$ Kurus $=\frac{117}{278}=0,420863309$

Label class $\mathrm{H}=$ Normal

Jumlah data dengan label class $\mathrm{Y}=$ Normal yaitu 3677 , hasil perhitungannya sebagai berikut:

$\mathrm{P}\left(\right.$ Jenis Kelamin $=$ Laki - laki $\mid$ Normal $=\frac{2031}{3677}=0,552352461$

$\mathrm{P}\left(\right.$ Jenis Kelamin $=$ Perempuan $\mid$ Normal $=\frac{1646}{3677}=0,447647539$

Label class $\mathrm{H}=$ Gemuk

Jumlah data dengan label class $\mathrm{Y}=$ Gemuk yaitu 89 , hasil perhitungannya sebagai berikut:

$\mathrm{P}\left(\right.$ Jenis Kelamin $=$ Laki - laki $\mid$ Gemuk $=\frac{53}{89}=0,595505618$

$\mathrm{P}\left(\right.$ Jenis Kelamin $=$ Perempuan $\mid$ Gemuk $=\frac{36}{89}=0,404494382$

Pada data numerik atau data kontinu, perhitungan probabilitas digantikan dengan densitas gauss. Perhitungan dilakukan berdasarkan data testing numerik yang telah ada sebelumnya pada tabel 2. Perhitungan densitas gauss hanya dilakukan pada atribut berat badan dan tinggi badan.

Untuk atribut berat badan $=7,4 \mathrm{~kg}$, proses dan hasil perhitungan densitas gauss diperoleh sebagai berikut:

$\mathrm{f}($ Berat Badan $=7,4 \mid$ Label Sangat Kurus $)=\frac{1}{\sqrt{2 \pi(2,53650893)}} e^{-\frac{(7,4-4,857142857)^{2}}{2(2,53650893)^{2}}}=0,09518056$

$\mathrm{f}($ Berat Badan $=7,4 \mid$ Label Kurus $)=\frac{1}{\sqrt{2 \pi(3,534645656)}} e^{-\frac{(7,4-8,492446043)^{2}}{2(3,534645656)^{2}}}=0,1076296$

$\mathrm{f}($ Berat Badan $=7,4 \mid$ Label Normal $)=\frac{1}{\sqrt{2 \pi(46,10739623)}} e^{-\frac{(7,4-12,28550721)^{2}}{2(46,10739623)^{2}}}=0,008606203$

$\mathrm{f}($ Berat Badan $=7,4 \mid$ Label Gemuk $)=\frac{1}{\sqrt{2 \pi(9,16501378)}} e^{-\frac{(7,4-16,83258427)^{2}}{2(9,16501378)^{2}}}=0,025637496$

Selanjutnya untuk atribut tinggi badan $=64,4 \mathrm{~cm}$, proses dan hasil perhitungan densitas gauss diperoleh sebagai berikut :

$\begin{aligned} \mathrm{f}(\text { Tinggi Badan } & =64,6 \mid \text { Label }=\text { Sangat Kurus })=\frac{1}{\sqrt{2 \pi(15,10681822)}} \mathrm{e}^{-\frac{(64,6-63,43928571)^{2}}{2(15,10681822)^{2}}} \\ & =0,026336937\end{aligned}$

$\mathrm{f}($ Tinggi Badan $=64,6 \mid$ Label Kurus $)=\frac{1}{\sqrt{2 \pi(18,13952456)}} \mathrm{e}^{-\frac{(64,6-79,27553957)^{2}}{2(18,13952456)^{2}}}$

$=0,015858521$ 


$$
\begin{aligned}
\mathrm{f}(\text { Tinggi Badan } & =64,6 \mid \text { Label Normal })=\frac{1}{\sqrt{2 \pi(14,09985787)}} \mathrm{e}^{-\frac{(64,6-85,63937721)^{2}}{2(14,09985787)^{2}}} \\
& =0,00929634
\end{aligned}
$$

$\mathrm{f}($ Tinggi Badan $=64,6 \mid$ Label Gemuk $)=\frac{1}{\sqrt{2 \pi(13,61679307)}} \mathrm{e}^{-\frac{(64,6-87,44269663)^{2}}{2(13,61679307)^{2}}}$

$$
=0,007175687
$$

\section{Menghitung Probabilitas Akhir}

Perhitungan probabilitas akhir dilakukan dengan cara mengalikan semua hasil nilai probabilitas atribut dan juga hasil densitas gauss. Hasil nilai probabilitas akhir yang diperoleh sebagai berikut:

a. $\mathrm{P}(\mathrm{H}=$ Sangat kurus $)=\mathrm{P}($ Berat badan $\mid$ Sangat kurus $) * \mathrm{P}($ Tinggi badan $\mid$ Sangat kurus $) * \mathrm{P}($ Jenis kelamin $\mid$ Sangat kurus)

$$
=0,006876228 \times 0,09518056 \times 0,026336937 \times 0,5
$$

$=0,00000861854163181961$

b. $\mathrm{P}(\mathrm{H}=$ Kurus $)=\mathrm{P}($ Berat badan $\mid$ Kurus $) * \mathrm{P}($ Tinggi badan $\mid$ Kurus $) * \mathrm{P}($ Jenis kelamin $\mid$ Kurus $)$

$=0,06827112 \times 0,1076296 \times 0,015858521 \times 0,579136691$

$=0,0000674858158701352$

c. $\mathrm{P}(\mathrm{H}=\mathrm{Normal})=\mathrm{P}($ Berat badan $\mid$ Normal $) * \mathrm{P}($ Tinggi badan $\mid$ Normal $) * \mathrm{P}($ Jenis kelamin $\mid$ Normal $)$

$=0,902996071 \times 0,008606203 \times 0,00929634 \times 0,552352461$

$=0,00003990614259853130$

d. $\mathrm{P}(\mathrm{H}=$ Gemuk $)=\mathrm{P}($ Berat badan $\mid$ Gemuk $) * \mathrm{P}($ Tinggi badan $\mid$ Gemuk $) * \mathrm{P}($ Jenis kelamin $\mid$ Gemuk $)$

$$
\begin{aligned}
& =0,021856582 \times 0,025637496 \times 0,007175687 \times 0,595505618 \\
& =0,00000239445784433354
\end{aligned}
$$

Setelah hasil perkalian diperoleh, kemudian dilakukan normalisasi terhadap hasil tersebut sehingga jumlah nilai yang diperoleh $=1$.

$$
\begin{aligned}
& \text { Sangat Kurus }=\frac{0,0000086185}{0,000008618+0,000067485+0,000039904+0,000002394}=0,07278948 \\
& \text { Kurus }=\frac{0,000067485}{0,000008618+0,000067485+0,000039904+0,000002394}=0,56996389 \\
& \text { Normal }=\frac{0,000039904}{0,000008618+0,000067485+0,000039904+0,000002394}=0,33702379 \\
& \text { Gemuk }=\frac{0,000002394}{0,000008618+0,000067485+0,000039904+0,000002394}=0,02022283
\end{aligned}
$$

\section{Membandingkan Hasil Normalisasi}

Setelah hasil normalisasi diperoleh, kita bandingkan semua hasil normalisasi nilai probabilitas yang menunjukkan nilai terbesar. Diperoleh probabilitas kelas kurus paling tinggi dengan nilai 0,56996389, maka data testing masuk kedalam klasifikasi kurus.

\section{KESIMPULAN}

Hasil pengujian data balita dengan jenis kelamin "laki-laki", berat badan 7,4 kg dan tinggi badan 64,6 $\mathrm{cm}$ mendapatkan hasil normalisasi yang terdiri dari sangat kurus sebesar 0,07278948, kurus sebesar
0,56996389, normal sebesar 0,33702379 dan gemuk sebesar 0,02022283. Setiap hasil normalisasi dibandingkan berdasarkan nilai terbesar, maka didapatkan nilai 0,56996389 yang paling besar sehingga hasil klasifikasi status gizi balita adalah "Kurus".

\section{DAFTAR PUSTAKA}

Dinas Kesehatan Aceh. (2018). Profil Kesehatan Aceh 2018.

Guntur, M., Santony, J., \& Yuhandri. (2018). Prediksi Harga Emas dengan Menggunakan Metode Naïve Bayes dalam Investasi untuk Meminimalisasi Resiko. Jurnal RESTI 
(Rekayasa Sistem Dan Teknologi Informasi), 2(1), 354-360.

Hariri, F. R., \& Pamungkas, D. P. (2016).

Implementasi Naïve Bayes Classifier Untuk diagnose Status Gizi Balita. Seminar Nasional Teknologi Informasi Dan Multimedia, 6-13.

Putri, R. A., Sendari, S., \& Widiyaningtyas, T. (2018). Classification of Toddler Nutrition Status with Anthropometry Calculation Using Naïve Bayes Algorithm. 3rd International Conference on Sustainable Information Engineering and Technology, SIET 2018, 66-70.

Rahmawati, E. (2017). Implementasi Program (Gentasibu) Gerakan Pengentasan Gizi Buruk Di Puskesmas Kecamatan Tanjunganom Kabupaten Nganjuk. Publika, 5(3).

Widiastuti, N. A., Santosa, S., \& Supriyanto, C. (2014). Algoritma Klasifikasi Data Mining Naïve Bayes Berbasis Particle Swarm Particle Swarm Optimization Untuk Deteksi Penyakit Jantung. Pseudocode, 1(1), 11-14. 